we read, "is it not virtually the only sane opinion, that Paul received this account (of the Last Supper) from his Lord mediately, through some disciple who was present, or through current tradition? Such, then, must be regarded as the true content of the apostle's idea of 'revelation'" (147). This in the face of Paul's positive assertion as to the source of his gospel in Gal 1:11.

In particular, Paul's doctrine of the atonement is assailed and condemned. We read: "Paul's idea of law, of penalty, of expiation, offends the modern sense of justice and contradicts our ethical values at every point of contact. Without caricature, it may be compared to ideas that prevail in certain police circles today. A sensational crime is committed; the public is greatly roused and demands detection and punishment of the criminal. This the police are unable to accomplish, but obviously something must be done to silence public clamor; so they 'frame up' a case against some one who can most plausibly be made the scapegoat. $\mathrm{He}$ is convicted by perjury, the ery is silenced, the majesty of the law has been vindicated, justice is satisfied!" Comment is surely needless on this caricature, which, of course, remains caricature no less though marked "without earicature."

Unfortunately this is not the only case in which we find gross failure fairly to state a doctrine to which the author is opposed, but the space of this review will not permit the statement, much less the consideration, of many other points on which most of his readers will differ and by the mere statement of which many will be profoundly saddened.

David Foster Estes.

Landmarks in the History of Early Christianity. By Kirsopp Lake. Macmillan \& Co. 113 pp. \$1.25.

This delightful and, in many respects, stimulating volume is made up of what was originally a series of lectures. This will, in some measure, account for so much of the "first person" element as well as for the rather patronizing attitude taken by the author to those who do not know enough to agree with him. The book 
is not a history. It is rather a series of opinions about history; some of which are excellent, some otherwise, but all interesting. It is a fine book for the student of history as an example of destructive criticism. The author speaks with the finality of the historian on many subjects which are by no means settled. The author boldly states that Christianity beeame nothing more than "a Graeco-Oriental cult, offering salvation, just as did the other mystery religions." He sees in Christianity nothing but a "synthesis" of the multitudinous religions into which it came. All of the early disciples were rather poor, deluded fellows who disagreed among themselves. Galilee, Jerusalem, Antioch, Corinth, Rome and Ephesus are his chapter heads. Each of these cities, he says, is associated with distinctive contributions to Christianity, which, according to the discussion, has nothing distinctive in itself. The author has done some excellent work in describing other religions. The main objection is in the failure to describe Christianity, concerning which he seems to know little.

F. M. Powell.

\section{RELIGION AND MISSIONS.}

China Awakened. By Min Ch'ien T. Z. Tyan, LL. D. (London), author of "London Through Chinese Eyes," "China's New Constitution and International Problems," and "The Legal Obligations Arising Out of Treaty Relations Between China and Other States": with special honorific endorsement by His Excellency Hsu Shih Ch'ang, President of the Chinese Republic, as well as introductions by Right Honorable Sir John Newell Jordan, K. C. B., etc., etc., and the Honorable Charles R. Crane, United States Minister to China. The Macmillan Company, New York, 1922. xvil-|-475 pp. $\$ 5.00$ net.

Besides the dignity of the several introductions noted in the title description, Dr. Tyan is commended by his having served as Technical Adviser to the Chinese Delegation to the Assembly of the League of Nations; by his service as Lecturer on International Law in Tsing Hua College, Peking, and by his founding and editing for some two years "The Peking Leader.' 